\title{
To whom do the dead belong? The Jewish cemetery at the Hôtel-Dieu in Lyon, France ${ }^{1}$
}

\author{
Jacques Gerstenkorn Université Lumière Lyon 2 \\ jacques.gerstenkorn@univ-lyon2.fr
}

\begin{abstract}
This article describes the powerplay around the recent discovery (summer 2015) of eighteenth-century Jewish graves in the French city of Lyon. Prior to the French Revolution, Jews had no right to have their own cemeteries, and the corpses of the deceased were buried in the basement of the local catholic hospital, the HôtelDieu. In recent years this centrally located building was completely renovated and converted into a retail complex selling luxury brands. The discovery and subsequent identification of the graves - and of some human remains - led to a complex confrontation between various actors: archaeologists, employed either by the municipality or by the state; religious authorities (mostly Lyon's chief rabbi); the municipality itself; the private construction companies involved; direct descendants of some of the Jews buried in the hospital's basement; as well as the local media. The question of what to do with the graves took centre stage, and while exhumations were favoured by both archaeologists and the representatives of the families, the chief rabbi - supported by the construction companies - proved reluctant to exhume, for religious reasons. In the first part of his article the author details the origins of this Jewish funerary place and current knowledge about it. He then goes on to analyse what was at stake in the long negotiations, arguing that the memory of the Holocaust played a role in the attitude of many of the parties involved. By way of conclusion he considers the decision not to exhume the graves and elaborates on the reasons why this led to some dissatisfaction.
\end{abstract}

Key words: France, Jewish graves, exhumations (refusal), Jewish law, Holocaust memory

Discovering a cemetery in the heart of a major metropolis is no trivial matter. Something happens akin to a return of repressed memories, as if the bodies buried in the ground, forgotten for generations, are suddenly remembered by the inhabitants of the city. The cadavers come out of their closet - as if on a ghost train - and their revival raises multiple questions: legal, ethical, religious, archaeological ones, as well as questions about heritage in contexts that are themselves quite varied. Depending on the case, these can disturb the peace or 
force the government to change the funerary laws, as French sociologist Arnaud Esquerre showed recently. ${ }^{2}$ And the situation becomes even more complex when it involves ancient Jewish sepulchres, due to the hypersensitivity that has prevailed since the Holocaust about anything relating to Jewish graves. The fact that millions of Jews murdered in the middle of the twentieth century had no grave at all makes it an even more precious discovery to find old cemeteries or the remains of Jewish bodies, even if they belong to a more distant past, as if their very presence was part of the mourning process. So, it seems necessary to clarify that the study that follows comprises two parts that should be distinguished methodologically from the outset. The first part is strictly historical: it documents the burial practices of the Jews on the site at the Hôtel-Dieu (hospital) in Lyon in the second half of the eighteenth century; the second part involves leaving behind the historian's approach and instead adopting the role of a committed participant in civic life. This second part is about recreating the story of the discovery of the cemetery in order to disentangle its various dimensions, whether economic, related to worship, political, related to the media, related to the community, legal, archaeological or also genealogical and private. Based on a central question that is fundamentally anthropological (to whom do the dead belong?), we will encounter issues that are related to memory, conflicts of interest and different scenarios for the fate of the human remains and their burial place - scenarios that will reveal in turn the different points of view of the main actors concerned.

But first, it is important to identify the context in which the Jewish cemetery of the Hôtel-Dieu came to exist. In the kingdom of France, for a long time the burial of non-Catholics was a thorny issue for the authorities. What was to be done with Protestants, Jews, as well as actors and people who died a violent death, whom people refused to bury in the parish cemetery, in consecrated ground? Historically, concrete answers to this general problem varied according to the place of death and status of the deceased. ${ }^{3}$ The 'Declaration of the King' made at Versailles on 9 April 1736 instituted a procedure authorising the local Juge de police (police judge) to order burials, but that did not solve every problem - to begin with, there was the issue of allocating burial spaces. ${ }^{4}$ Meanwhile, in the second half of the eighteenth century, Jews began once again to live in Lyon, the second city of the kingdom, from where they had been officially banished in $1394 .{ }^{5}$ However, it was out of the question to bury Jews in the parish cemeteries of the churches of Lyon, which were strictly reserved for Catholic burials. So it was that the Hôtel-Dieu hospital agreed, as it had done for Protestants for centuries, to make a burial space available for Jews - without, however, selling them the land. For this reason, in eighteenth-century Lyon, unlike in Bordeaux or Paris, where Jewish cemeteries opened at the same time, the Jews did not own their own cemetery.

Thanks to the Livre d'instruction (Instruction Manual) written in 1776 by the Hôtel-Dieu's prêtre économe (priest-bursar), Jean-Claude Prin, we know the procedure followed on the death of a member of the 'Jewish nation' (in the words used at the time). In a chapter entitled 'De la sépulture des Juifs' ('On the Burial of the Jews') which follows the chapter on the burial of members 'de la religion prétendument réformée' ('of the Supposedly Reformed Religion') funerary protocol 
is strictly codified. ${ }^{6}$ We can note here the accounting dimension of the event: the cost of the funeral was 108 livres (in the local currency), of which 9 livres were for digging the pit and 3 livres for sending off the death certificate, which was no small sum for a bereaved family, especially if it was a family of pedlars. ${ }^{7}$ But this cash infusion also represented an appreciable sum for the Hôtel-Dieu at a time when the institution, heavily indebted, faced financial difficulties that forced the rectors to apply for assistance from the municipal government and to sell a part of their many properties. ${ }^{8}$ One can note, for that matter, the deep involvement of the prêtre économe at all stages of the proceedings, since he was the one who took note of the burial order and gave the order for a pit to be dug. Burials of Jews were to take place at night, as was the case for Protestants, following a custom that had been made official by the Edict of Amboise in 1562. The rectors of the hospital did not attend these funerals; only the prêtre économe accompanied the burial, and he added the death certificate to the register of non-Catholic deaths. ${ }^{9}$ Jean-Claude Prin was therefore the privileged interlocutor for Jewish trustees throughout that period and he was no doubt responsible for the bulk of the arrangements made for Jews in Lyon by the office of the hospital.

From 1746 to 1793 the records of the Hôtel-Dieu noted forty-five burials of people identified as belonging 'to the Jewish nation'. ${ }^{10}$ The chronology of these burials attests to the increasing power of the Jewish presence in Lyon throughout the second half of the century: a single death prior to 1759, ten deaths from 1759 to 1774 , thirty-four deaths from 1775 to 1792 . Most importantly, the notes in the death records provide information on the geographical origin of those immigrants. We can distinguish three groups of equal size: a first group, which represents about a third of the burials, consists of Sephardic Jews from the Comtat Venaissin (these are the famous 'Pope's Jews'); another third is made up of members of the Ashkenazi rite of Jews, who are from foreign countries, mostly from Germany; the third and final group is made up of those who had left Alsace or Lorraine. But from a religious, cultural and sociological perspective, the latter two groups were homogeneous: indeed most of them were pedlars who struggled to feed their families and spoke Yiddish. In contrast, the group of Jews from the Comtat Venaissin, who spoke Provençal, were much more integrated: specialised in the fabric business, they were actively engaged in trading in the sector. The group's members included merchants who were often wealthy, the richest of them residing in the district around the place des Terreaux, while pedlars lived around the place Confort, ${ }^{11}$ close to the Hôtel-Dieu. The composition of the 'Jewish nation' in Lyon was far from homogeneous but, despite its social fragmentation, it featured an embryo of community organisation with a trustee and a deputy trustee (always chosen from among the noteworthy Comtadins), an oratory ${ }^{12}$ and a rabbin sacrificateur (a certified rabbi who slaughtered animals according to orthodox Jewish ritual), who made it possible to consume kosher meat. ${ }^{13}$ During the same period in Paris, Ashkenazi Jews, who were buried in Montrouge, and the 'Portuguese' Jews, buried in the cemetery of La Villette, proved incapable of creating a shared cemetery; in Bordeaux, Portuguese Jews and Avignon Jews had also decided, at least initially, to create separate cemeteries. In Lyon, until 1795, when the Jews acquired a burial 
ground in the neighbourhood of la Mouche,$^{14}$ it is not irrelevant to note that the cemetery at the Hôtel-Dieu welcomed Jews of all backgrounds, both Sephardic Jews from the Comtat and Ashkenazis from the Rhineland, inside the compound of a Catholic hospital and close to the Protestant cemetery.

\section{A little more than two centuries later ...}

In the early 2010s, in an agreement with the Hospices Civils de Lyon (Lyon Civil Hospitals), the landowners, the city government of Lyon, decided to definitively close the hospital, including its maternity ward, where several generations of Lyonnaise women had given birth. In June 2015 a press release announced the acquisition of the Hôtel-Dieu by a bank and the conclusion of a '99-year building lease' with the Hospices Civils de Lyon, which remain the owners of the land. ${ }^{15}$ The development project envisions the transformation of the Hôtel-Dieu, renamed 'Grand Hôtel Dieu de Lyon', into an emblematic space devoted to the art of Lyonnaise living, planned to include before the end of this decade (and the mayor's term in office) a luxury hotel, la Cité internationale de la gastronomie (the International City of Gastronomy), a convention centre, upmarket shops and some housing. The proposed scheme was accompanied by a protective measure classifying the entire perimeter of the Hôtel-Dieu as a historic monument, thus paving the way for systematic archaeological monitoring within the framework of a so-called 'preventive archaeology' procedure. The procedure would be carried out alongside the development of the site by a construction company chosen by the city of Lyon to lead this massive project. In the city of Lyon - which in 1930 was the first municipality to have an archaeological service (the SAVL $)^{16}$ - searches are not conducted by INRAP (the National Institute for Preventive Archaeological Research): ${ }^{17}$ they are recommended by the state, represented regionally by SRA (the Regional Archaeology Service), but their implementation is delegated to SAVL at the municipal level. During the 'archaeological evaluation' phase a survey was conducted on a portion of the site on the order of 8 to 10 per cent of the area to be explored, the city government of Lyon taking responsibility for the costs of the operation. If the initial investigation led the SRA to prescribe a thorough search, the developers would be responsible for paying for it. Later we will see that these economic subtleties are not unrelated to the strategy of the planners when they were confronted with what, for them, represented an archaeological obstacle, something that could slow down their work. ${ }^{18}$

The municipality's resumption of full control of the site was a last chance to find Jews buried at the Hôtel-Dieu; until then they had never been the object of any field survey within the confines of the hospital. However, that chance could be seized only if the Jewish cemetery area was located at the initial investigation site itself. It is certainly appropriate to note that the concern to locate the old cemetery was long-standing, encouraged by an investigation conducted into a Jewish family that had emigrated from Avignon to Bordeaux in the early eighteenth century: the Perpignan family, one of whose sons, Abraham Perpignan, had moved to Lyon in the 1770 s to become a silk merchant there. ${ }^{19}$ In January 1784 , perhaps suffering 
from a cancer, Abraham Perpignan became so weak that he could not leave the room-cum-shop that he occupied on the first floor of the Hôtel d'Angleterre. On 18 January, Abraham sent for a notary, maitre Macors, to dictate his will. ${ }^{20}$ Fifteen days later, at the age of 42, Abraham died. A long legal proceeding pitted the heir of Abraham Perpignan, David Naquet, against the royal domain, which intended to exercise the droit d'aubaine (the right to confiscate a deceased foreign national's property). It was a proceeding that would lead to the recognition of David Naquet's right to inherit his brother-in-law's estate. ${ }^{21}$ But what became of the body of Abraham Perpignan? Where was it buried? At the end of the nineteenth century, in a note published in L'Univers israélite on the topic of the history of the Israelites in Lyon, ${ }^{22}$ Chief Rabbi Alfred Lévy reported the existence of a Jewish cemetery at the Hôtel-Dieu in the second half of the eighteenth century and recorded the names of Jews in the register of non-Catholics who had certainly died outside of the hospital but were buried within its walls. And it is precisely in this register that this can be found: on 1 February 1784, the certificate recording the burial of Abraham Perpignan. That having been said, the paper trail revealed nothing about the location of the cemetery. In his voluminous Nouvelle histoire de Lyon (New History of Lyon) published in 1895, the Lyonnaise André Steyert had indeed offered a hypothesis about the location, with the letter 'Tav' printed on a diagram of the site, but this suggestion was based on personal intuition and was not founded on documentary evidence or on-site excavation: it was later revealed to be inaccurate. And much more recently the issue of location remained for many Lyonnaises a subject of curiosity and investigation; ${ }^{23}$ in fact it was doubted whether people would ever find physical traces of the burial place of the Jews at the Hôtel-Dieu.

It is thanks to an article by Olivier Zeller on the pollution of Lyon cemeteries in the second half of the eighteenth century ${ }^{24}$ that it was possible to solve the puzzle. At the end of 1777 a royal commission was organised to study the state of the cemeteries of Lyon. ${ }^{25}$ It was composed of representatives of the municipal government and doctors - as well as architects and surveyors who were given the task of creating a topographical map of Lyon's cemeteries. Each cemetery was thus entitled to a visit from the commission. On the topic of the Hôtel-Dieu, a detailed report was prepared in early 1778 on the burial conditions of Protestants and Jews. It included a map of the denominational cemeteries at the Hôtel-Dieu (but not the one reserved for the sick), a map that displays successive concessions granted to the Jews. A first location of very modest dimensions (it measured only ' 20 pieds de ville' in length - or 6.85 metres) was next to the Protestant cemetery, from which it was separated by a wall. It was used from 1759 to 1774 . Ten people - six adults and four children - were buried there. Then, at the request of Aron Ravel and Abraham Perpignan, deputy trustee and trustee, respectively, of the Jewish nation in Lyon, the office of the Hôtel-Dieu granted the Jews a new burial site located in the basement of the pharmacy building, ${ }^{26}$ designated with the names 'Jewish basement at the hospital' on the map and 'crypt of the Jews' in the description written by the commission's reporter. At the bottom of the map, information entered in pencil specifies the way to access it, a route from a staircase with twelve steps leading into the courtyard and down into the cellar of the pharmacy: 'We came to the basement 
of the Jews through a cave 114 pieds long and 16 pieds 9 pouces wide. ${ }^{27}$ It was in this 'crypt', between the years 1775 and 1793, that thirty-four Jewish corpses (thirteen adults and twenty-one children) were buried.

The state's archaeological services, informed of this discovery of evidence, were highly responsive: 'We did an overview this afternoon with my colleagues who worked on this case', writes Luc Françoise-dit-Miret, an engineer in the archaeology service at DRAC (the Regional Directorate of Cultural Affairs) for the Rhône Alpes region. ${ }^{28}$ ' C. Ducourthial (SAVL) created an overlay of the map you saw (and which he digitised) based on the map of the existing basement and the elevation. This set of maps, compared with the texts, shows clearly that there are two burial spaces on either side of the Protestant cemetery (to put it simply ...). The "crypt," the second burial location, is located near the old pharmacy on the western boundary of the Protestant cemetery, or about 40 metres from the first location. This is an easily accessible basement that I have visited in the past. As for the "first" cemetery, it is currently located under an existing building that does not have a basement.'

There was therefore a meeting at the site of the Hôtel-Dieu on Monday, 6 October 2014 at 9:30 a.m. to investigate what was underneath the courtyard of the pharmacy. After this field visit, all data from the 1778 topographical survey were confirmed at the site and there remained no doubt as to the location of the crypt. As its use as a burial location had been completely forgotten for over two centuries it had become a very ordinary basement, criss-crossed by exposed pipes and filled with storage benches ... But from that day a new question arose: what should be done with this basement? And how would the various parties concerned react?

Locating the eighteenth-century burial place of Lyon's Jews at the far western end of the underground gallery that runs under the old basement of the pharmacy concerned, first and foremost, their descendants. To be sure, one would have thought that a jump of eight to nine generations would have erased the link between our contemporaries and their ancestors. But our age demonstrates a lively curiosity about genealogical research, especially in the field of Jewish genealogy; ${ }^{29}$ moreover, for around ten years the increasing digitalisation of a large number of archives, beginning with the vital records kept in various departmental archives, has facilitated access to and the use of data to a considerable degree. This was enough to trace some of the branches, both direct and indirect, of people buried at the Hôtel-Dieu. This was particularly the case for the Perpignan family (Abraham, Blanche and their daughter Régine) and for the Gaffré family, ${ }^{30}$ or for Sara Todret, married to Moïse Nathan, a merchant and silk pedlar whose descendant happens to be a woman known for her competence as a member of Jewish genealogical associations. A remark by the psychiatrist Michel Hanus makes complete sense here: ${ }^{31}$ 'A social group, whatever it may be, from the family to the nation, is shaped by its living members and soon will be by their descendants, but it is also shaped to a large extent by its elders and its ancestors - and by its dead, whose existence it is useful to bear witness to with visible and lasting signs.'

We must insist on this point: in the case of the Hôtel-Dieu de Lyon, the fact that there is no break in the chain that binds the dead to the living was crucial not only in the process that led to interest in and discovery of the burial sites, but also in the 
fact that the civil authorities were alerted; later, so were the developers; and, even later, Jewish institutions and opinion about the future of those very sites. Thus, in the wake of the identification of the crypt, beginning in October 2014, the developers received a 'wish' urging them to preserve the site, remove the pipes and demolish the storage benches in order to dedicate the space to the memory of those who were buried there. ${ }^{32}$ At the same time a copy of the request was sent to the regional director of cultural affairs, who in turn asked the regional prefect what would be involved in granting the request.

Here it should be noted that the developers did not wish to respond to the request immediately. Did this silence reflect their discomfort at being faced with a request that could hamper the work that was in progress? At the same time, how could they ignore a request that had reached the state authorities in the region; and if they did not consider it, might this offend Jewish citizens and spark protests from local sources - major local Jewish institutions (CRIF [Representative Council of French Jewish Institutions], Consistoire Israelite [Israelite Consistory])? In spring 2015 , perhaps on the advice of the city government, the developers, anxious not to make a mistake, contacted the head regional rabbi, the only interlocutor officially recognised by the civil authorities. This contact marked a turning point in the handling of the case because it introduced a new actor of a religious type. Even better, it put in place a kind of authority representing the entire Jewish population (we can see in this the legacy of a Napoleonic tradition), the exclusive holder of the right to prescribe the way forward. A question of memory and archaeology with highly symbolic content was thus moved into the religious realm, as if the fate of the Jewish dead was ultimately a matter for the rabbis. And, in fact, the chief rabbi was invited, along with the judge from the rabbinical court, to visit the site, beginning in mid-June 2015. On the day of the visit the chief rabbi had taken the initiative to alert a photographer from Le Progrès, the local newspaper in Lyon, which covered the news of the discovery of the Jewish cemetery on its front page. ${ }^{33}$ Confronted with this publicity, the companies in charge of construction began to protest. Following this episode, the chief rabbi was asked by the office of the mayor of Lyon not to have any dealings with the press without prior consultation; this demonstrated the willingness of the city government to avoid controversy, and perhaps also its concern to limit the publicity given to the burial sites discovered at the Hôtel-Dieu site.

On Thursday, 16 July 2015, the archaeological department of the SAVL, executing instructions from the state services and under the supervision of the chief rabbi and the rabbinical judge, began the archaeological evaluation project in the courtyard of the pharmacy (corresponding to 'unit six' of the Hôtel-Dieu archaeological site), land that had to be cleared as soon as possible in order to install the technical infrastructure for the future convention centre. The site evaluation began with the first survey located in the 'Jewish section', which took place in accordance with Jewish traditions (an e-mail from the chief rabbi stated that the work carried out at the Jewish site was to end on Friday at 4:30 p.m. at the latest, in order to respect the Sabbath). The surveys, which as a general rule affect only about 8 to 10 per cent of the terrain, brought to light scattered bones of very young children and adults - but 
no complete skeleton - which can easily be explained by the violent disruptions that the site underwent over the course of the nineteenth century, in particular due to the demolition of the pharmacy building and the construction of a laundry facility in the garden., The human remains were carefully collected, but they were not sent to the archaeological laboratory; the rabbinical authorities (particularly the judge) strongly opposed any scientific examination. At the request of the rabbinical judge, to make sure that the bones would not crumble, they were not handled at all. However, they were exhumed, so that they could be handed over definitively to the Jewish community. The chief rabbi had them (re)buried in a small section of alley $S$ at the consistory's cemetery of La Boisse, located twenty-five kilometres from Lyon on the plain of the Ain River. ${ }^{34}$ On 30 July 2015, human remains were collected and placed in three different graves, now identifiable by their small golden plates indicating for each of them whether they contain the remains of children or adults, or a mixture of the bones of adults and children. It was impossible to assign either of these terms to the ten individuals who were buried there. During the month of August the chief rabbi organised a religious funeral ceremony in La Boisse, but without publicising this religious moment too much. A fourth grave was to be created on 16 December 2015: it received the remains of children found during excavations in the portion of the Jewish cemetery that had not been analysed in July of the same year.

Alerted to these findings, the chief rabbi of France chose to leave the decision making to the regional chief rabbi. As for the curator in charge of Jewish heritage at the Ministry of Culture, he did not think it appropriate to go to Lyon in the absence of any stelae; the Jewish cemetery at the Hôtel-Dieu hardly aroused any curiosity on the part of those in charge of questions of history and historical value, despite a growing interest in funerary archaeological questions. ${ }^{35}$ To me, it seemed necessary to produce two texts of very different natures. The first text, entitled 'Mémorandum sur les inhumations juives à l'Hôtel-Dieu de Lyon dans la deuxième moitié du XVIIIe siècle' ('Memorandum on the Jewish Burials at the Hôtel-Dieu of Lyon in the Second Half of the Eighteenth Century'), was truly historical; it was published on 20 July on the website of the Jewish association GenAmi, and then shortly thereafter in Lyon communal publications. ${ }^{36}$ The second text was of a different nature: it entailed adopting a public position that would be spread by the media. It was entitled 'L'ancienne nécropole juive de Lyon doit être respectée' ('Lyon's Old Jewish Cemetery Must Be Respected') and was published in the electronic version of the newspaper Le Monde on Friday, 24 July. ${ }^{37}$ This was an opportunity to make public the desire to see the crypt preserved and protected and the hope for it to become 'a space for spirituality and meditation' rather than a basement slated for commercial use. Picked up by most Jewish Parisian institutions, this editorial attracted a certain amount of attention on social networks. However, the city government of Lyon did not appreciate this public gesture that violated the confidentiality requested by stakeholders, and it was embarrassed by this hardline, public position. ${ }^{38}$

A meeting was organised more than three months later, on Thursday, 19 November 2015, in a room at the city hall. The construction companies began by giving a presentation on the development of the area concerned, which was a zone inaccessible to the public, a space assigned for the storage for goods sold by 
the luxury shops located on the upper level. Then I was responsible for giving an update on the identification of families descended in direct or indirect line from the deceased resting at the Hôtel-Dieu, present-day people asking those in attendance to protect the crypt. The deputy mayor objected, since the crypt, unlike Jewish cemeteries in Bordeaux and Paris from the second half of the eighteenth century, did not include visible tombs and could not therefore be considered, strictly speaking, as a cemetery. This paved the way for a philosophical examination: is a cemetery a set of graves or simply a place where bodies are buried ${ }^{39}$ Then the chief rabbi, questioned about the compatibility of the development with the principles of Jewish law, said that as long as the intended use was not inappropriate - as would be the case if it included a plan to open a nightclub - he could not oppose the project proposed by the construction companies, provided, however, that they included an open space of ten centimetres between the current ground level of the crypt and the new concrete slab. This space was requested in order to comply with the laws of purity that are the responsibility of the Cohanim, the tribe that once ensured the operation of the Temple of Jerusalem and whose descendants must at all costs avoid coming into contact with dead bodies (this being the reason why a Cohen does not have the right to enter a cemetery). As for the archaeological services, they asked to proceed with a thorough archaeological evaluation of the crypt. It was finally agreed to meet again at city hall once the initial investigation was complete, in order to draw conclusions from it.

In March 2016 the archaeological survey, conducted, as per the instructions of the SRA, by archaeologists from SAVL, confirmed that the crypt was a funerary space. In this particular case, the conditions of the evaluation had been the subject of an agreement between the developers and the SRA: unusually, there would not be a survey on a portion of land, but a search that would cover the entire surface of the crypt (about sixty square metres). However, there was a crucial detail in the flow of the operation (and, as we know, the devil is in the detail): what is called 'the depth of development', which refers to the depth to which the SAVL was allowed to dig. It was initially set at 1.2 metres, but was reduced by the developers to eighty centimetres, in their manifest desire not to be confronted with the discovery decomposed bodies at the bottom of the pits: such a discovery would have triggered more thorough excavations, which would have entailed both a waste of time and the loss of money for the developer. Moreover, this also had the advantage of satisfying the rabbinical order, whose invariable course of action is not to disturb the resting place of the dead, the order of the chief rabbi being to stop the investigation once three or four sets of bones were found in order not to disturb the bodies. Thus a paradoxical situation developed in which the decision was made to search, but in a way that would entail finding as little as possible. Unlike what was happening at the same time nearby and on a large scale inside the Protestant cemetery, where the remains of more than a thousand bodies were exhumed and sent for laboratory analysis without the pastor finding anything wrong, it was expressly prohibited for SAVL archaeologists to go down to the level where the skeletons of Jewish bodies would appear, let alone to undertake any scientific analysis, not to mention possibly taking DNA samples that could be compared to the DNA of descendants - 
a procedure that could lead to identifying the bodies lying in the holes. For the sake of completeness on this point, note that, despite these requirements, which limited in advance the scope of the evaluation, archaeologists discovered the skeleton of a young child at the depth of development of one of the holes, only sixty centimetres below the original ground level. It was decided that it would be carefully reburied.

However, the archaeological evaluation of the crypt did deliver exciting results which led to a restitution during a further meeting at the city hall, on 28 April 2016. ${ }^{40}$ Under the concrete poured in the twentieth century, archaeologists first uncovered pebbles that had come to cover the original soil in the nineteenth century. By removing this stony layer they reached the floor of the crypt as it had existed at the time of the burials. However, a small strip of land at the western edge, as well as the north end of the basement, could not be reached in March, due to the (exposed) pipeline network. ${ }^{41}$ The summary of the results of the archaeological evaluation was presented by the director of the archaeological service. She reported: ' 24 graves to which must be added those located in the unexcavated areas. They can probably be taken to be the burials cited by the texts.' To an eye experienced in discerning the difference between the earth filling and the ground surrounding the hole, the layout of these pits is readily identifiable on the surface, the south central part of the crypt being an exception, where the holes overlap each other because of the lack of burial space that likely occurred at the end of the period when the crypt was in use. ${ }^{42}$ 'Chronologically', writes Olivia Puel, 'the graves belong to two distinct phases of burial. Initially, they are regularly arranged next to each other. ${ }^{43}$ They are mostly oriented east to west, although some of them, due to the ancient masonry, are oriented north to south. Their locations seem scrupulously respected despite probable burials in the same grave.' Even more puzzlingly, archaeologists also found some immature bones at the top of the filling of some graves, in an erratic position. ${ }^{44}$ They were again carefully reburied.

In summary, the burial pits were identified and mapped, but they could not be searched unless, we repeat, this was done at the prescribed depth (80 centimetres), much less than the depth (over 1.50 metres) where, according to information provided by the report of 1778 , the bodies had been buried. Once the archaeological operations are completed, the pits will be covered by a new elevated slab raised 10 centimetres above the floor of the crypt. Prior to this, also at the request of the chief rabbi, each pit was covered with a white sheet and a thin layer of soil was deposited on the original ground of the crypt to protect it from possible disruption by building equipment during the construction of the slab. The pits are thus fated to become what is called an 'archaeological reserve' in case further research one day (a necessarily distant one) becomes relevant. Despite the attested presence of the holes, the position of the chief rabbinate of Lyon, which was opposed on religious grounds to an invasive archaeological dig that would have disturbed the rest of the dead, prevented further archaeological study and the scientific investigation of human remains. But the work by SAVL still identified the location and configuration of the burial sites of Lyon's eighteenth-century Jews. Finally, let us note that in that the dénouement of this case the challenges of memory have not been forgotten. After the rehabilitation of the site the city government of Lyon is committed 
to putting up a plaque perpetuating the memory the Jews buried at the Hôtel-Dieu. The proposal of the deputy charged with memorial matters is to place the plaque not in the crypt, which is inaccessible to the public, since it is reserved for commercial use, but on the surface, inside the new Hôtel-Dieu in a place busy enough to enjoy a certain visibility. Thus, although their actual place of burial will not be recognised, the Jews who died in Lyon in the eighteenth century are slated, more than two centuries after their burial, to be given a memorial location in a public space. ${ }^{45}$

In this case, each of the five major stakeholders argued its reasons and its point of view: the developers have taken charge of the rehabilitation as well as the promotion of a historic monument (this dimension is an important part of the renovation project), but the fact must not be obscured that they must above all ensure the commercialisation of rehabilitated areas; the city authorities, although anxious not to see the progress of construction hampered by the discovery of a cemetery, nevertheless proved attentive to rabbinical prescriptions to which, from a strict legal point of view, Republican and secular law did not obligate them to commit; the consistory rabbinical authorities, who scrupulously ensure that people touch human remains as little as possible, prohibited any scientific work on the remains, but they accommodated separating the memorial location (where the future plaque will be) from the location of the burial of bodies; the SAVL, whose intervention is constrained by the framework set by the state and the rules of preventive archaeology, allowed the authentication of the burial sites and, thanks to the investigation done in the crypt, enabled the mapping of the graves; finally, the descendants of the families buried at the Hôtel-Dieu secured a promise from the city that there would be a memorial gesture - but not a preserved and protected crypt. ${ }^{46}$ After the development process ends, the oldest identified Lyonnaise Jewish site will again become ... a basement, and not a burial plot. Covering the Jewish graves with a new slab will allow the site to be allocated for commercial use, even if it is for storage, and means burying the cemetery itself; ${ }^{47}$ at the site, the holes will not be visible or accessible to the public. Despite the preservation of the site, its development will contribute to the material erasure of its use as a funerary location, even though this will be explicitly mentioned in the commercial leases. The crypt is to become what is called an 'archaeological reserve', meaning that the human remains were not exhumed or destroyed (they benefit directly from the maximum protection received by the Hôtel-Dieu as a historical monument), but the funerary space itself, although steeped in history, is not recognised as such. As we wait for the day, necessarily far from now, when recognition could really occur, it is important at least to preserve and to spread the memory and the trace of the first Jewish cemetery in Lyon in the modern era, as well as of the people who are buried there.

\section{Notes}

1 Translated from author's French by Cadenza Academic Translations.

2 Arnaud Esquerre, Les os, les cendres et L'État (Paris: Fayard, 2011).

3 In France, preventive archaeology has uncovered three medieval Jewish cemeteries: in Chalons in Champagne, in Ennezat and in Chateauroux. The case 
of the medieval Jewish cemetery in Chateauroux, surveyed in 1997 but since then completely devastated following a real estate transaction, was presented by Philippe Blanchard as part of the symposium 'Archéologie du judaïsme en France et en Europe', organised by INRAP (the National Institute for Preventive Archaeological Research) and the Musée d'art et d'histoire du judaïsme (Museum of Jewish Art and History) on 14 and 15 January 2010 in Paris. Also of note in this context was the presentation by Neil Asher Silberman (University of Massachusetts, Amherst), entitled 'Qui se soucie des morts? L'intervention archéologique dans les nécropoles: entre droits religieux et responsabilité civique?'

4 'Déclaration du Roy, concernant la forme de tenir les registres de Baptêmes, Mariages, Sépultures, Vestures, Noviciats \& Professions; et des Extraits qui en doivent être delivrés. Donnée à Versailles le 9 Avril 1736. Registrée en Parlement' ('Declaration by the King on How to Maintain the Registries of Baptism, Marriage, Burial, Taking the Veil, Novice Exercises, and, Professions; and Extracts that Must Be Made from Them. Made at Versailles 9 April 1736. Recorded by Parliament'), article 13.

5 In Lyon, historians date the actual expulsion of the Jews to the 1420 s.

6 Cf. J.-C. Prin, Livre d'instructions [Instruction Manual], 1776, Municipal Archives of Lyon: 'The Jews also have their burial place inside the Hôtel-Dieu; they must have the order from the commandant when they come to notify the économe [priest-bursar] who notes their name, surname, age, country and qualities of the deceased, and therefore orders the hole, and sets out a number of lanterns that are lighted when the funeral happens, which is ordinarily at 10 in the evening. The rectors do not come to these funerals. The économe is responsible for it, taking care upon their arrival to ask for the order and keep it; Jews must - and this is agreed for all the funerals of that nation - give him before or after the funeral, if one has not already done so when they came to notify you, the sum of 96 livres and nine livres for the boys which made the pit. In the Premier Bureau, he then hands 96 livres to the treasurer. (...) At least three livres are required for sending these certificates.'

7 To such an extent that Benjamin Naquet, then a trustee of the Jewish nation, made a petition, unanimously accepted (it should be stressed) by the office of the Hôtel-Dieu on 13 November 1785, to the effect that the poor would pay only 12 livres, the rich would still pay 96 livres ('following their old agreements'). This development reflects the growing number of poor pedlars who came to settle in Lyon throughout the 1780 s.

8 A. Croze describes a financial disaster caused by an overly ambitious reconstruction programme, Histoire du grand Hôtel-Dieu de Lyon [The History of Lyon's Hôtel-Dieu] (Lyon: Audin et Cie, 1924), 115. Cf. M.-C. Lecomte-Dinet, 'Les hôpitaux sous l'Ancien Régime : des entreprises difficiles à gérer ?' Histoire, économie et société, 18:3 (1999), 527-45.

9 On this matter, the protocol varies for Protestants: the rectors attended the burials, the number of rectors present depending on the rank of the deceased. Social hierarchy remains in death.

10 Cf. the table of burials published by J. Gerstenkorn in 'Mémorandum sur les 


\section{Jacques Gerstenkorn}

inhumations juives à l'Hôtel-Dieu de Lyon dans la deuxième moitié du XVIIIe siècle' ['Memorandum on the Jewish burials at the Hôtel-Dieu of Lyon in the Second Half of the Eighteenth Century'], GenAmi, http://www.genami.org/sujetde-la-semaine/hotel-dieu-lyon.php.

11 Today it is place des Jacobins.

12 On this topic we notably have the precious testimony of Hida (Hayim Yossef David Azoulai), who passed through Lyon in August 1778. Cf. Haïm Harboun, Les Voyageurs Juifs au XVIIIe siècle (Aix-en-Provence: Editions Massoreth, 1997), 311-21.

13 The sacrificateur was named Barouh Lévi and was buried at the Hôtel-Dieu under the name 'Bénédict Levi' (he is number 32 in the table of burials). His papers, found in the departmental archives (cote 8B 1012/2) include, among other documents, two manuscript 'shehita' certificates in Hebrew, signed by eminent rabbinical authorities passing through Lyon (first, in 1766, Rav Margaliot who taught the Talmud to the Gaon of Vilnius, then, in 1769, Rav Caligar, an emissary from Hebron, at that time en route to London). However, despite these certificates, Rav Azoulay refused to eat meat during his stay in Lyon.

14 The La Mouche cemetery grounds were purchased in 1795 for a sum of 12,000 livres by Aron Bloch, Mayer Gougenheim, Isaac Simon, and Bernard Alcan.

15 Cf. Crédit Agricole Assurances, 'Communiqués de presse', http://www. ca-assurances.com/espace-media/credit-agricole-assurances-et-eiffage-signentcession-du-grand-hotel-dieu-de-lyon-dans (accessed 24 July 2016).

16 Became le Service archéologique de la Ville de Lyon (SAVL) (Archaeological Service of the City of Lyon).

17 Institut national de recherches archéologiques préventives.

18 A spokesperson for the conversion of the historic building calls this a "bad surprise': 'Most of the work of "cleaning" the building is now complete and the work should not reveal any bad surprises,' hopes Claire Bertrand, from the architecture firm AIA. 'As usual, as soon as they started digging in Lyon, the project was indeed slowed by discoveries: new excavation projects revealed a Jewish cemetery from the eighteenth century and rare Roman frescoes on a black background.' M.-A. Blin, 'Le Grand Hôtel-Dieu de Lyon fait peau neuve' ['Lyon's Grand Hôtel-Dieu Is Being Completely Renovated'], Le Figaro (Paris), 10 June 2016.

19 His father, Jacob Perpignan, had left Avignon in 1718 to settle in Bordeaux. A drapery merchant, he had four sons: Moyze and Salomon, who settled in Paris, Abraham, who went to Lyon, Elie, who put down roots in Bordeaux. The whole family made a living by selling fabric.

20 The minutes of maitre Macors, E 6213, Departmental Archives of the Rhone.

21 In 1776, Jacob Perpignan had obtained letters patent from King Louis XVI granting him personally and to his descendants the status of French national. The court therefore recognised the validity of Abraham's will and dismissed the claim of the royal prosecutor.

22 Alfred Levy (chief rabbi of Lyon), 'Notice sur l'histoire des Israélites de Lyon' ['Notes on the History of Lyon's Israelites'], L'Univers israélite, 1894. Closer to our 
time, let us note the work of E. Dreyfus and L. Marx, Autour des juifs de Lyon et alentour [About the Jews from Lyon and the Surrounding Area], published 'under the auspices of the Consistoire israélite de Lyon [Israelite Consistory of Lyon]' in 1958 - in particular the chapter entitled 'Au XVIIIe siècle on enterre les Juifs aux lanternes dans les caves de l'Hôtel-Dieu' ['In the Eighteenth Century, Jews Were Buried by Lantern Light in the Basement of the Hôtel-Dieu'], 131-4.

23 Cf. for example the response on 8 November 2007 by the municipal library of Lyon: information taken from Mrs Chantal Rousset, archivist at the Hôtel-Dieu museum, 'The Jewish and Protestant cemetery no longer exists: the graves would have been excavated in the nineteenth century (that's when we begin to take public health issues seriously, and what's more the Hôtel-Dieu was in constant expansion throughout the century).' 'Guichet du Savoir', Bibliothèque municipale de Lyon [Lyon Municipal Library], http://www.guichetdusavoir.org/viewtopic. php? $\mathrm{f}=2 \& \mathrm{t}$ $=26077 \& \mathrm{p}=48453 \&$ hilit=cimetière + juif $\#$ p48453 (accessed 15 June 2016).

24 Cf. Olivier Zeller, 'La pollution à Lyon par les cimetières urbains, pratiques funéraires et discours médical à Lyon en 1777’, Histoire urbaine, 5 (2002/1), 67-83.

25 'Rapport de la commission d'enquête Gesse de Poisieux sur les cimetières lyonnais, en particulier sur les cimetières protestants et juifs de l'Hôtel-Dieu, avec le plan des cimetières' ['Report from the Gesse de Poisieux Investigative Commission on Lyon's Cemeteries, Particularly the Protestant and Jewish Cemeteries at the HôtelDieu, With a Map of the Cemeteries'], 1778, AD 1 B6, Departmental Archives of the Rhone.

26 This request is reproduced in Dreyfus and Marx, Autour des juifs de Lyon et alentour, p. 132.

27 One pied is roughly equivalent to a foot and a pouce is analogous to an inch.

28 E-mail dated Thursday, 2 October 2014.

29 In France there are two associations dedicated to Jewish genealogy: le Cercle de Généalogie Juive (CGJ, the Circle of Jewish Genealogy) and the GenAmi association.

30 Cf. J. Gerstenkorn, 'Avant-propos à la saga Gaffré', http://www.genami.org/saga/ saga-gaffre-avant-propos.php.

31 'Les traces des morts. Nécessité pour les proches et pour la société de savoir où se trouvent le corps ou les cendres des défunts', Etudes sur la mort [Studies on Death], 132 (2007), 39-44, quoted in Esquerre, Les os, les cendres et L'État, p. 103.

32 E-mail dated 10 October 2014.

33 Le Progrès of Lyon, 17 June 2015.

34 Opened in 1970, the Jewish Memorial of La Boisse was created to bring together the remains of the Jewish victims of the events of 1940-45 and to allow the burial of members of Jewish communities in the Lyon region. Cf. in particular, R. Wertenschlag, Histoire des juifs à Lyon (Rillieux-la-Pape: Salomon, 2016), pp. 53-6.

35 Cf. in particular, the work of Groupe d'anthropologie et d'archéologie funéraire (GAAF, The Anthropology and Funerary Archaeology Group), http://www.gaafasso.fr.

36 J. Gerstenkorn, 'Mémorandum sur les inhumations juives à l'Hôtel-Dieu de Lyon 
dans la deuxième moitié du XVIIIe siècle (1746-1792)', 20 July 2015, http:// www.genami.org/sujet-de-la-semaine/hotel-dieu-lyon.php; http://www.kerenor. fr/wp-content/uploads/2015/07/inhumations_hd.pdf; Bulletin du Consistoire israélite de Lyon [Bulletin of the Israelite Consistory of Lyon], No. 202, SeptemberOctober-November 2015 (Tishrei-Cheshvan-Kislev 5776).

37 Le Monde (Paris), 24 July 2015, lemonde.fr.

38 A meeting was convened at city hall on Tuesday, 28 July by the deputy responsible for heritage and memory. After a slightly tense exchange, the deputy mayor proposed to bring together at city hall all the interlocutors concerned: spokespeople for the site's development, the chief rabbi of Lyon, the regional archaeology service and the city's archaeological department. We had agreed that I would attend the meeting as a representative of the families buried at the Hôtel-Dieu.

39 'The field of Jews' in Ennezat in the Auvergne, the only entirely preserved medieval Jewish cemetery, includes about 800 graves buried in a field, without any of them being apparent. The site has been protected as a historical monument at the request of the Consistoire Central (Central Consistory).

40 Restoration completed on 19 July 2016 by an exchange at SAVL with Vianney Rassart, assistant director, and Olivia Puel, spokesperson for the crypt operation. This summary is supposed to be published later by the SAVL at the same time as the result of excavations carried out throughout the entire Hôtel-Dieu site.

41 The pipes were removed and the archaeological diagnostic process resumed on 25 July 2016. This last phase of exploration has revealed eight new pits, bringing to thirty-two the number of marked graves, very close to the total of thirty-four dead known from the documentary sources (given the saturation of the space, it may be that some pits were, unusually enough, the site of multiple burials).

42 The mapping of the graves in the crypt is to be published in the final archaeological report.

43 This regularity of their alignment is particularly noticeable along the west wall.

44 Also of note is a pit near the crypt entryway which appears at a level that dates to later than the original floor of the basement.

45 To this end, during the April meeting, the chief rabbi made sure to give the deputy mayor a text that precisely recalls the historical conditions of the burial of Jews at the Hôtel-Dieu.

46 It is noteworthy that before installing the new slab on 6 September 2016, developers allowed me to bury three white stones in the floor of the crypt, to mark that we had visited the pits, according to the traditional Jewish custom. Since the new slab involved raising the soil level, modifying the state of a listed building, the developer had to pay the state a significant penalty.

47 It is the very presence of a cemetery in the midst of luxury in Lyon that seems inappropriate in the eyes of developers, as well as the city government of Lyon. This reluctance to make the cemeteries visible in the city seems to be part of a broader trend in Western societies toward 'disguising cemeteries'. Cf. J.-D. Urbain, L'Archipel des morts. Le sentiment de la mort et les dérives de la mémoire dans les cimetières d'Occident (Paris, Plon, 1989). 